\title{
A Himnusz regényes története a Magyar zene és kultúra zenepedagógiai konferencián
}

\section{Hegedüsné Tóth Zsuzsanna}

\author{
Eötvös Loránd Tudományegyetem Tanitó- és Óvóképzö Kar
}

Az Eötvös Loránd Tudományegyetem Tanító- és Óvóképző Karán 2021 januárjában, a hagyományt megőrizve, ismét megrendezésre került a kar Ének-zenei Tanszékének szervezésében egy országos szintű szakmai énekzene pedagógiai konferencia - idén online formában. A konferencia előadásai, programjai a Magyar zene és kultúra címmel jelzett téma köré szerveződtek. Az immár 11. alkalommal megrendezett konferencia különleges színfoltja a konferencia vendégeivel, Becze Szilviával - a Bartók Rádió szerkesztő-műsorvezetőjével - és Tóth László Csabával - a Budapesti Filharmóniai Társaság elnökével - folytatott beszélgetés volt. A beszélgetés apropója a konferencia másnapján, $A$ magyar kultúra napján a világhálón elérhetővé váló $A$ Himnusz regényes története címü dokumentumfilm. Ebben a filmben működött közre mint zenei szakértő, Becze Szilvia, illetve az Erkel Ferenc által alapított, Tóth László Csaba elnöklése alatt működő Budapesti Filharmóniai Társaság. A konferencia-résztvevőknek lehetősége volt belenézni a film egyes részleteibe, valamint megismerkedni a film készülését irányító elképzelésekkel.

A konferencia indításaként tehát a magyarságtudatunkat magában hordozó nemzeti himnuszunkról, kultúránk szerves részéről beszélgettünk a film nyomán. A filmben Juhász Anna irodalmár és Becze Szilvia zenei szakértő „beszélgetésébe ágyazottan” megismerhetjük a Himnusz számos irodalmi és zenei vonatkozását, születését, illetve az a kort, amelyben keletkezett, illetve Kölcsey Ferencet és Erkel Ferencet, kortársaikat, azt őket inspiráló kort, amikor műveik születtek, és azt, ahogy azok nemzeti identitásunk hordozóivá lettek.

A Himnusz regényes története címü film azóta is elérhető a Budapesti Filharmóniai Társaság YouTube csatornáján ${ }^{1}$, de a nagy érdeklődésre tekintettel számos website is megosztotta.

A Himnusz keletkezése és utóélete számos izgalmas, regényes fordulatban bővelkedik, fedezték fel a film készítői, a Budapesti Filharmóniai Társa${ }^{1}$ https://www.youtube.com/watch?v=1iPMW8Rb9jI\&ab_channel=Filharm\%C3\%B3niaiT\%C
3\%A1rsas\%C3\%A1g 
ság és az Erkel Ferenc Társaság, s ezt érdemes edukációs céllal is terjeszteni. A 30 perces filmet az NKA is érdemesnek tartotta a támogatásra. A Himnusz regényes története címü film animációkon, videóbejátszásokon keresztül számos érdekesség mellett, szórakoztató epizódokkal tárja a nézők elé a Himnusz történetét. A felidézett anekdotákból körvonalazódik, hogy Egressy Béni, a Szózat zeneszerzője is adott be pályaművet a Himnusz megzenésítésére 1844-ben kiírt pályázatra, sőt csupán néhány szavazaton múlt, hogy most nem azt énekeljük ünnepi alkalmakkor.

Megtudhatjuk a filmből azt is, hogy miért alkalmaztak a pályázatban kottamásolókat, hogyan eshetett meg, hogy pontatlan jeligét kapott Erkel Ferenc munkája, valamint hogyan fogadta az akkori közvélemény Erkel Ferenc szerzeményét. A film felhívja a figyelmet arra, hogy az elmúlt közel 100 évben valójában Dohnányi Ernő áthangszerelésében énekeljük hazánk legemblematikusabb dallamát, emellett bemutatja a legfontosabb különbségeket Erkel Ferenc eredeti műve és Dohnányi Ernő átdolgozott verziója között.

A film szakreferense Somogyváry Ákos, Erkel Ferenc szépunokája, és az Erkel Ferenc Társaság elnöke lett, aki örömmel tett eleget a felkérésnek. A filmmel párhuzamosan - a Budapesti Filharmóniai Társaság gondozásában - elkészült egy weboldal ${ }^{2}$, amelyen a zenekar előadásában meghallgatható az összes fennmaradt korabeli pályamü, így Erkel Ferenc eredeti himnuszverziója is. Az online felületen Batta András zenetörténész is összefoglalja a Himnusz történetét. Mivel a film készítőinek nem titkolt célja, hogy az oktatás számára igényes, hasznos segédanyagot adjanak közre, a kezdeményezés részeként egy idővonal segítségével, képekkel illusztrálva, jól áttekinthető módon nyomon követhetővé tették a Himnusz napjainkig tartó történetét .

A kezdeményezés sikerességét bizonyítja, hogy hasonló koncepciók mentén létrejött és egyaránt elérhető $A$ Szózat regényes története című dokumentumfilm ${ }^{3}$.

\footnotetext{
${ }^{2}$ www.magyarhimnusz.hu

${ }^{3}$ https://www.youtube.com/watch?v=eXpQa0iye3s\&ab_channel=Filharm\%C3\%B3niaiT\%C3 \%A1rsas\%C3\%A1g
} 